\title{
Görünür Olma Arzumuzu Görünür Kılan Ayşe Bayramoğlu Oyunları: Hakiki Gala ve Beyaz Yalanlar
}

\author{
Ayşe Bayramoğlu's Plays That Make Visible Our Desire to Be \\ Visible: Genuine Gala and White Lies
}

\author{
Elif Aydın ${ }^{1}$ (1)
}

'Öğretim Görevlisi, Doğuş Üniversitesi, Sanat ve Tasarım Fakültesi Oyunculuk Bölümü, Istanbul, Türkiye

\section{ORCID: E.A. 0000-0001-7227-6039}

Sorumlu yazar/Corresponding author: Elif Aydın,

Doğuş Üniversitesi, Sanat ve Tasarım Fakültesi Oyunculuk Bölümü, Istanbul, Türkiye

E-posta/E-mail: 90elifaydin@gmail.com

Başvuru/Submitted: 28.09 .2020

Revizyon Talebi/Revision Requested:

11.10.2020

Son Revizyon/Last Revision Received:

11.10.2020

Kabul/Accepted: 16.11 .2020

\section{Atıf/Citation:}

Aydin, Elif. "Görünür Olma Arzumuzu Görünür Kılan Ayşe Bayramoğlu Oyunları: Hakiki Gala ve Beyaz Yalanlar" Tiyatro Eleştirmenliğive Dramaturji Bölümü Dergisi 31, (2020): 45-65. https://doi.org/10.26650/jtcd.801052

\section{öz}

Bu çalışma, 2000 sonrası tiyatro yazınımıza katkı sunan Ayşe Bayramoğlu'nun Hakiki Gala ve Beyaz Yalanlar oyunlarını, geç küreselleşme ve medyanın ürünü olan yeni bir kitlesel seyir deneyimi ve görünür olma arzusu ekseninde incelemeyi amaçlamaktadır. Her iki oyunda da "reality show" dünyasının bir parçası olma arzusu taşıyan ve bunu gerçekleştirmeye çalışan karakterlerin bulunduğu ve aynı zamanda bu görünür olma çabasının oyun içerisinde bir noktada if̧̧a edildiği görülmektedir. Gerçek hayatlarından daha "sahici" ve göz önünde olan hayatlara imrenen bu karakterlerin çabalarının tiyatro sahnesinde boşa düşmesinin, tıpkı bu karakterler gibi kendilerini hiçbir durumda yeterince özgün hissedemeyen çağımız insanı ve tiyatro seyircisinin seyir deneyimine nasıl bir etkisi olabileceği de çalışmanın tartışma zeminini oluşturmaktadır.

Anahtar Kelimeler: Ayşe Bayramoğlu, 2000'ler, Reality Show, Görünür Olma Arzusu, Hakiki ve Kurmaca

\section{ABSTRACT}

In the axis of a new mass viewing experience and the desire to be visible, which is the product of late globalization and the media, this study examines Ayşe Bayramoğlu's Hakiki Gala and Beyaz Yalanlar, which have contributed to the post-2000 theater literature. In both plays, there are characters who desire to be a part of a "reality show" world to make it happen, and, simultaneously, this effort at being visible is revealed in each play. This study inversigates also how the futile efforts of these characters who envy lives more "real" and visible than theirs might affect the viewing experience of people and the theater audience, who, just like these characters, cannot feel authentic enough under any circumstances.

Keywords: Ayşe Bayramoğlu, 2000s, Reality Show, Desire To Be Visible, Authentic and Fictional 


\section{EXTENDED ABSTRACT}

It is a fact that the media, whose roots can be traced to liberal policies wherein the separation of private and public spheres of the 1980s was blurred, is a medium where the increasing desire for visibility is pumped the most. It was during these years that the intimate and private stories were displaced, and the boundary between fiction and reality gradually faded. Our acquaintance with competition-game genres of reality TV began during the 2000 s, when reality TV programs were prepared with a journalistic approach derived from page-three news in the reality show format that was introduced by private television channels. Such programs started being broadcasted in the 1990s. As a result of late globalization and neoliberal policies, individuals feel inadequate and will disappear unless they make themselves visible and constantly put themselves in the circulation of the media and the market as a commodity. Therefore, it can be said that we are fed and guided by the motto, "I am visible, therefore, I am."

The two plays that Ayşe Bayramoğlu wrote in 2010 and in 2012 that will be examined in this article concern this search for authenticity of ordinary people. Hakiki Gala (Genuine Gala) is about two characters who create a life story for themselves from the page-three news and use a novelist (fictional character of Ayşe Bayramoğlu herself) to become famous. However, after narrating their tragic stories and how they met, they admit that they are actually making use of the audience for their fame. Specifically, these two characters adapted their back stories from various kinds of page-three news and always desired to be visible and authentic like the people on the news. In contrast, Beyaz Yalanlar (White Lies), carries a reality show competition named "White Lies" to the stage along with its backstage preparations. The play witnesses how contestants try to make their ordinary lives special and how they are deceived by their neighbors which they use for the reward at the end of the competition (and the play itself). Their neighbors whom they consider as having happy lives and their "real" life, as they later admitted, are not really appealing; however, they choose to deceive themselves and others with white lies. Both texts have a structure that reveals this search for authenticity and the effort to be visible.

In addition to the examples of plays wherein the dominant discourse is reproduced on the theater stage, independent theater groups also shed light on these "ordinary lives" and try to find a space to express themselves on stage. In theater, which considered as having an important place in terms of breaking the conventional watching habits of today's audience as well as the illusion created by television, Bayramoğlu's disclosure strategy has a valuable place and can make important contributions to the post-2000 theater literature in Turkey. While Hakiki Gala focuses on the narrator persona that today's audience can regard as charismatic, in Beyaz Yalanlar, the imaginary fourth wall of the theater stage is transformed into a solid wall -just like a television screen- by means of a curtain. In other words, although these two plays are 
formulated around the same theme, they follow two different strategies in terms of staging the world of reality shows. Nonetheless, they have a common strategy in revealing our effort to be visible and our search for authenticity.

In our 2000s theatrical climate, where performative narratives are widespread, Ayşe Bayramoğlu's Hakiki Gala and Beyaz Yalanlar may have a special place in terms of narration and staging. When examined these two play together, how a similar problem can be presented to the audience differently can be seen more clearly. 


\section{Giriş}

Günümüz insanı olarak hakikatimiz ve özgünlüğümüz konusunda şüpheye düşmüş durumda olma gerçeğimizin izini sürerken 80'ler Türkiye'sine dair yapılan tespitlerden faydalanmak yarar sağlayabilir. Zira, Nurdan Gürbilek'in ifadesiyle dille olan ilişkimizi kökünden değiştirmeyi başarması ve "dille hakikat arasındaki ilişkiyi koparırken hayali bir dili sahiciymiş gibi gösterebilmesi" ${ }^{1}$ bakımından bu dönem kimliklere bakış anlamında önemlidir. Bunun yanı sıra, 80’lerin liberal politikalar ve hâkim söylemin alan açtığı "sözde özgürlük ortamı" ile özel hayatın ve mahrem olanın medya aracılığıyla sentetik bir dil eşliğinde kamuya sunulduğu bir dönem olduğu söylenebilir. Önceden kimsenin birbirine yabancı olmadığı, kendi kimliklerini bırakarak belli birtakım kutuplaşmış toplumsal kimlikler üzerinden örgütlenebildikleri kamusal alan $^{2}$ 80'lerle birlikte çok daha özgürmüş sanısı uyandırsa da kamu, özelin medyayla göze sokulması ve teşhirle adeta teatral bir sahaya dönüşmüştür. 90'larda yürütülen neoliberal politikalar kapsamında yayın hayatına başlayan özel televizyon kanalları da birkaç yıl içerisinde "reality TV" formatını habercilik iddiasıyla yavaş yavaş hayata geçirmiş ve en gerçek özel hayatların medyanın sundukları olduğunu kanıksar duruma gelmemizi sağlamıştır. Ülkemizde asıl gerçeğin yavan bulunup sahte olanın ulaşılamaz ve büyüleyici konuma erişmesi ise milenyum çağı 2000'lerde “reality” formatının yeni türü ile tanışıklığımıza dayandırılabilir. 90'larda üçüncü sayfa gazete haberciliğinin televizyon ekranlarına reality show olarak taşınmasının ardından 2000'lerle birlikte uzun yıllar farklı formlarda görmeye aşina olacağımız bu tür, "yarışma-oyun" şeklinde kategorize edilen reality show programlarının ta kendisidir. ${ }^{4}$ Özetle, 2000'lerle birlikte televizyonun haber nakletme niteliği hızlı bir şekilde erozyona uğramaya başlayınca ve her türlü toplumsal, siyasal ve ekonomik eylem "gösteri toplumu"nun meşruiyet zemini olan eğlence kültürünün ve medyanın ${ }^{5}$ bir parçası haline geldikçe, hem icracı hem de izleyici olarak Tayfun Atay'ın deyimiyle “Meşhuriyet Çağı”nın meşhur olmaktan başka bir çaresi olmayan rakipleri ${ }^{6}$ haline gelmiş bulunmaktayız. Neoliberalizmin yönetimsel aklının günümüzde güçlü bir görünürlük arzusuyla birlikte belirdiğini düşünen Sarıkartal'a göre de,

Kişi, ezik olmadığından ve kendini makbul normlara uygun bir şekilde yönettiğinden ancak başkaları kendisini görünmek istediği şekilde gördüğ̈̈nde emin olabiliyor. İmajının başkalarının nazarında net bir şekilde onaylanmasına ihtiyaç duyuyor. Sanki insanlar toplumsal çevreleri onları takdir etmediği anda kendi özgünlüklerinden şüpheye düşüyorlar. Bunun sonucunda, tahmin edeceğiniz üzere, kendilerini makbul tarzda sunmaya, toplumsal ortamlarda daha fazla görünmeye ama aynı zamanda da "cool” görünmeye çalışıorlar. Ben

\footnotetext{
Nurdan Gürbilek, Vitrinde Yaşamak: 1980 ’lerin Kültürel İklimi (İstanbul: Metis Yayınları, 2001), 25. a. e., 64-65.

Bilgehan Ece Şakrak, "Gerçekliğin Kurgulanmasında Reality-Show’lar” (Doktora tezi, Marmara Üniversitesi, 2014), 180.

6 Tayfun Atay, Görünüyorum O Halde Varım: “Meşhuriyet Çăgı”"nda Kültür ve İnsan (İstanbul: Can Yayınları, 2018), 57.
} 
bu kafa yapısının kendinde bir eksiklik hissi ve buna bağll özgün ötesi bir kendilik araylşılla karakterize olduğunu düşünüyorum. Bir başka deyişle, insanlar basitçe hayatlarını yaşamak yerine, paradoksal bir biçimde, davranışlarını özel bir farkındaki halinde icra ettiklerinde sanki kendilerini daha güvenli ve özgün hissediyorlar. Açıkça söylemek gerekirse, bu, hayatta kendini oynama şeklinde beliren bir tür oyunculuk. Bu olgunun [...] ciddi belirtileri ise "reality show" türünden televizyon programlarındaki abartılı performanslarda gözlemleniyor. ${ }^{7}$

Bu görünürlük arzusunu tiyatro cephesinde inceleyen Sarıkartal'ın analizine paralel olarak Atay da "Görünüyorum, o halde varım" mottosuyla beslenir ve güdümlenir hale geldiğimizi ${ }^{8}$ belirtmektedir. Her iki akademisyenin de sözünü ettiği bu teatral çağda tiyatro da haliyle, tıpkı televizyon gibi bu kültür ve eğlence endüstrisinin bir parçası; kitlesel seyir deneyiminin belirleyicisi konumundadır elbette... Her ne kadar televizyonun giderek büyümüş hâkimiyeti yanında esamesi bile okunamayacak bir pozisyonda olduğu düşünülse de tiyatronun, hem yadsınamayacak denli gerçek karşılaşmaların yaşanabileceği hem de televizyonun yarattığı illüzyonu kırabilecek yegâne cephe olduğunu savunmak yersiz olmayacaktır. İşte tam da bu noktada tiyatro, seyircinin konvansiyonel seyretme alışkanlıkları ve beklentilerini sahne üzerinde yeniden üretmek ya da yerleşik illüzyonu bozmak anlamında bir seçim yapmak durumunda olabilir.

Bu yazının konusu olan görünürlük arzusunu mesele eden Hakiki Gala ve Beyaz Yalanlar oyunlarıyla karşımızda duran Ayşe Bayramoğlu, kendini ve yaşadığı dünyayı aciz ve umutsuz ${ }^{9}$ bulduğunu ifade eden; fakat bu acizliği ve umutsuzluğu var eden dinamikler üzerine düşünmeyi, merak etmeyi ve yazmayı bırakmayan bir yazardır. Kendisi bir yazar olarak ne aradığını ise şu şekilde özetlemektedir:

Bir ekip için oyun yazıyorsam onlardan gelen çıkış noktasının bendeki karşılığını arıyorum. Beni şaşırtan, korkutan, gıdıklayan olay, fotoğraf, müzik, şiir; her şey, üzerine yazılabilir bir metin haline geliyor. Trajikomik olanın peşindeyim. ${ }^{10}$

Tiyatrotem ile birlikte ürettiği ve Tiyatro... Tiyatro... Dergisi tarafından "Yılın Oyun Yazarı" ödülüne layık görüldüğü Hakiki Gala (2010) ve yüksek lisans tezi kapsamında yazım sürecini ve taslağını kaleme aldığı Beyaz Yalanlar (2011) metinleri de, hissettiğimiz yetersizlik hissiyle hesaplaşmaya ve görünür olmaya çalışırken nasıl çırpındığımızı, ironiyle ortaya koymaya çabaladığı metinler olarak değerlendirilebilir. Sahne üzerinde kurduğu dünyayı seyircinin nasıl alılmadığını ve alımlayabileceğini dikkate alarak metin üreten yazar, yazı kapsamında incelenmeye çalışılacak Hakiki Gala ve Beyaz Yalanlar oyunlarında farklı teatral stratejiler

7 Çetin Sarıkartal, "Varsayılan Kullanıcıyı Kenara Bırakmak: Neoliberalizm, Sinirbilim ve Oyuncu Eğitimi”, Dikmen Gürün'e Yazllar içinde, Haz. Yavuz Pekman, Oğuz Arıcı (İstanbul: Doğan Kitap, 2020), 515.

8 Atay, Görünüyorum O Halde Varım: "Meşhuriyet Çă̆l” nda Kültür ve İnsan, 59

9 “Bu 'Pencere' Sizi Utandırmak İçin Açıldı”, Cumhuriyet, 30.12.2012, erişim 23.09.2020). https://www.cumhuriyet. com.tr/haber/bu-pencere-sizi-utandirmak-icin-acildi-394206

10 Bahar Çuhadar, "Yerli oyun yazarlarının 5N1K'sı”, Radikal Hayat, 2012. 
deneyerek tiyatronun güncelliğini ve ontolojik varlığını sorgulamaya ve reality show fenomenini tartışmaya alan açmıştır.

\title{
Temsilin Temsilinin Tiyatrosunu Yapmak: Edibe Ayşen Kutlugil'in Eserinden Hareketle Hakiki Gala Oyunu ${ }^{11}$
}

\begin{abstract}
Hakiki Gala serüvenim başladiğında henüz bu serüvendeki rolümün farkında değildim. Bir yazar olma yolunda 'tay tay' bir duruş sergiliyor, ürkek adımlarla ama inatla yürümenin ve bir yol oluşturmanın derdiyle koşturup duruyordum. 'Bizim bir fikrimiz var' dediler, onları tanıdı̆̆ım kadarıyla bu fikrin o anda akıllarına gelmediğini, aylardır zihinlerinde oradan alıp buraya koyarak pişirdiklerini biliyordum. Sizlerin de yukarıda günlüklerde okuduğunuz kadarıyla ben her zamanki gibi bu oyuna reji asistanı olarak başladım. Ve bana göre birdenbire, onlara göre tam kolladıklart vakitte oyunun yazarı oluverdim. [...] Yazmak birçokları için olduğu gibi benim için de tekil bir eylem. Aam kısa adıyla Hakiki Gala'yı yazmak tamamen bir ekip işiydi. Ortada benim olmayan ama benimseyebileceğim bir fikir vardl. Benzer konuların derdine düşmüştük farklı zamanlarda. ${ }^{12}$
\end{abstract}

Bayramoğlu'nu "nadir bulunacak işbirliğinden"13 doğduğunu ifade ettiği Hakiki Gala oyununun sahneleme metninin iskeleti Tiyatrotem ekibinin kolektif masa başı tartışmaları sonucu yapılan doğaçlama çalışmalarla şekillenmiş ve Bayramoğlu tarafindan metnin diyaloglarının oluşturulmasıyla sahneleme metni can bulmuştur. ${ }^{14}$ Dolayısıyla Hakiki Gala oyununu ele alırken Tiyatrotem'in tiyatro anlayışından da söz etmek gerekmektedir. 2001 yılında Ayşe Selen ve Şehsuvar Aktaş tarafından kurulan Tiyatrotem'in tiyatroya bakışını özetleyen Ayşe Selen, “çağdaş ve geleneksel gösterim sanatları tekniklerini dramatik tiyatro ile Türkiye kültürel ortamında kaynaştırma esasına dayanan araştırmacı bir tiyatro" ${ }^{15}$ olduklarını ve Tiyatrotem' in “bir anlamda tiyatronun tiyatrosunu yapmayı arzulayan, bunu araştıran bir 'anlatı tiyatrosu' olduğu"nu belirtmektedir. ${ }^{16}$ Tiyatrotem' in, tiyatronun kurmaca olduğunun altını çizme konusunda geleneksel tiyatromuzla konuşan ve onun araçlarından beslenen işler üretmesinin yanı sıra "anlatı tiyatrosu” yapıyor oluşu önemlidir. Çünkü özellikle son yıllarda, yerli ve yabancı oyunlarda dramatik olanın yerini anlatısal olana birakması ya da tiyatronun bu ikili yapısının bir aradalığının vurgulanması eğiliminin dikkat çekici boyutta olduğu görülmektedir. ${ }^{17}$ Hakiki Gala fikrinin filizlenmesinde ve oyunun teatral zemini

11 Hakiki Gala oyununun teatral zemininin derinlikli bir şekilde ele alındığı birçok önemli çalışma bulunmaktadır. Tüm bu çalışmaların derlemesi için bkz: Mimesis Tiyatro/Çeviri-Araştırma Dergisi, İstanbul: Boğaziçi Üniversitesi Yayınları, 18 (2011).

12 Ayşe Bayramoğlu, “Oyun Yazarının Bir Sahne Metni Oluşturmak Üzerine Deneyimleri”, Hakiki Gala (İstanbul: Mitos-Boyut Yayınları, 2010), 47.

13 a. e., 48.

14 a. e., 47-48.

15 Tiyatrotem, Ayşe Bayramoğlu'nun Hakiki Gala adlı kitabına önsöz (İstanbul: Mitos-Boyut Yayınları), 5.

16 a. e., 5.

17 Yunus Emre Gümüş, “2000 Sonrası Çağdaş Türk Tiyatrosunda Yeni Bir Estetik: Performatif Anlatı”, Uluslararası Disiplinlerarası ve Kültürlerarası Sanat Dergisi, 6 (2018), 241. 
bağlamında önemli bir yeri olduğu belirtilen ${ }^{18}$ Klasik Dramatik Metinleri Bugün Buradan Anlatmak makalesinin yazarı ve oyunun dramaturgluğunu ve yönetmenliği üstlenen Çetin Sarıkartal da bu değişime işaret etmektedir. Sözü edilen makalede aynı zamanda öykü anlatımı ekseninde son dönemde Batı' da gerçekleştirilen projelerin "performans sanatı, belgesel film ya da reality-show ad verilen televizyon programlarından esinlendiği" ${ }^{\prime \prime}$ savunulmaktadır. Geç küresel kapitalizmin yarattığı yeni bir ruh hali olduğundan; kendi özgün varlığından şüpheye düşen insanın sürekli olarak görünür olduğunu hissetme çabasına girdiğinden bahseden Sarıkartal, tam da bu ruh halinin "çıplak gerçeği sansürsüz bir biçimde temsil etmeye yönelik" ${ }^{20}$ bir çaba doğurduğunu; sahne üzerinde gerçek ötesi ya da aşırı özgün anların aranmasının ardında kişinin bu toplumsal koşulların bir sonucu olarak kendinde duyduğu yoksunluk ve eksiklik hissinin bulunduğunu düşünmektedir. ${ }^{21}$ Ayrıca Sarıkartal, bunun yalnızca sahne cephesinde değil, seyir yeri cephesinde de bir karşılığı olduğunu; seyircinin tam da kendisi gibi banal olduğu için sahne üzerindeki "hakiki" anlatılara ve "normal” anlatıcılara dair bir merak taşımadığını eklemiştir. Bunun neticesinde de günümüz seyircisinin bugünün anlatıcısından karizmatik olmasını beklediğini, bu beklentiyi karşılamak üzere Batı tiyatrosunda postdramatik girişimler görüldüğünü açıklayan Sarıkartal'a göre, bu prodüksiyonlarda yine de etkili olan şey biçimsel farklılık değil daha ziyade ele aldıkları konular ve metindir. Çünkü merkeze alınması gereken "insanların nesneleştirilmelerini değil de kendi yaşamlarına eleştirel bir konumdan bakabilmelerini sağlama"22 durumudur ve çağdaş oyunlarının bu anlamda özgünlüğünü sağlayan unsurun da bu paradoksun farkındalığ1 olduğu düşünülmektedir:

Bugünün anlatıcısından beklenen şey karizmatik olması, yani özgünlüğün bir kez daha özgünleştirilmiş bir halini sunması ise, tiyatro sahnesinde sözde gerçeği anlatma ve gösterme girişimleri nasıl özgün olabilir? [...] Özgünlüğü sağlayan şey, kimi örneklerde gösterimin gerçeklik sanısı yaratan sınırlar içinde kalmakla birlikte gerçekliği parodiye kadar varabilen bir farkındalık içinde temsil etmesi, kimi diğer örneklerde ise anlatımın, Walter Benjamin'i izleyerek betimlemek gerekirse, kendisine yaklaşıldıkça uzaklaştığı duygusu uyandıran, auratik bir anlatıcı karakterinden yapılmasıdır. Bunların her ikisinin de temelde metinsel, dolayısıyla dramatik bir stratejiye dayandı̆̆g ileri sürülebilir. ${ }^{23}$

Bu anlamda Tiyatrotem'in Hakiki Gala'daki stratejisi de "kendini tüm çıplaklı̆̆ıyla toplumun zalim seyrine sunarak karizma oluşturma çabasını”24 görünür kılmak olmuştur. En aşırı örnekleri reality show programlarında görülebilecek kendini kurbanlaştırma durumuyla ve medyanın

18 Tiyatrotem, önsöz, 5-7.

19 Çetin Sarıkartal, "Klasik Dramatik Metinleri Bugün Buradan Anlatmak”. Tiyatro Araştırmaları Dergisi, 29 (2010), 67.

20 a.e., 70 .

21 a. e., 68-69.

22 a. e., 71.

23 a. e., 70-71.

24 a. e., 70. 
kamuya taşıdığı hayatların hakikati ve temsiliyetiyle ilgilenen Tiyatrotem de prova sürecinde bunu sahnelemeye dair niyetlerini şöyle açıklamaktadır:

Biz bunu tiyatro sahnesinde gerçek bir "reality show" gibi yapmayacağız. Bunu "alıntılayacağız”. Özgün olma çabasının ve buna dair girişimlerin "tiyatrosunu” yapmak istiyoruz. "Reality show" özellikleri taşlyan gösterimler (ya da tv programlarl) aslında hakikatin değil de, yine bir temsilin temsiliyse, temsilin temsilinin tiyatrosunu (temsilini) yapmak nasil olur acaba?25

Sarıkartal'ın ortaya koyduğu günümüz insanının ve seyircisinin “tiyatro"sunu; özünde “temsilin temsilinin temsili”"ni yapma şiarıyla işe koyulan ekip de, metne ek olarak yayınladıkları prova notlarında yer verildiği üzere, diğer oyunlarında da olduğu gibi sahne üzerinde bir arada bulunacak iki anlatıcının öncelikle birbirleriyle ve seyirciyle nasıl bir ilişkileri olacağını düşünmeye ve çeşitli doğaçlamalar yapmaya başlamıştır. Yazar Ayşe Bayramoğlu'nun da hazır bulunduğu provalarda, bu tuhaf ikilinin arka planına dair, “...y yarışmalardan firlamış olabilirlerdi ya da tek hayalleri bu yarışmalarda yarışanlar gibi kendilerini göstermek olabilirdi " ${ }^{26}$ şeklinde çeşitli öneriler ortaya atılmış ve neticede bu ikilinin kendilerine "üçüncü sayfa" haberlerinden bir geçmiş ve kimlik yaratmış olmasında karar kılınmıştır.

Ellerinde oyunun kendisinin yazılı olduğu -henüz isimsiz- bir kitapla seyirci karşısına çıkacak olan bu ikilinin, oyunun ilk yarısında yer yer hikâyelerini anlattıkları ve anlatı sırasında anlatıma kapılıp seyirciden koptukları, yer yer de çalıştıkları oyunu unutacak kadar heyecanlanıp ellerindeki kitaba döndükleri bir kurguyu takip etmesi fikri sabitlendikten; yani giriş, öndeyiş ve üçüncü sayfa haberlerinden derledikleri yaşam öykülerini seyirciye anlattıkları bölümlerin neredeyse son halini almasından sonra oyunun halen bir anlatı zemini olmadığını düşünen ekip, şu fikirle oyunun kurgusuna son şeklini vermiştir:

Oyunun devamından önce çözülmesi gereken bir sorun vardı. Bu tuhaf ikili bütün bunları niye anlatıyordu? Bunların anlatıldığını süren kitap nereden çıkmıştı? Yazarı kimdi? Kendileri mi yazmışlardı? Yoksa bu onlar için yazılmış bir oyun muydu? Bu bir oyun muydu peki? Dili neden böyleydi? Düşünüldü, tartışıldı ve ellerindeki kitabın romandan uyarlanan bir oyun olduğuna karar verildi. Romanı yazan Edibe Ayşen Kutluil adında bir yazardı. Edibe Ayşen Kutlugil tamamen uydurma bir isimdi ve o prova gününde oyunu yazmakla görevlendirilen Ayşe Bayramoğlu'nun isminden türetilmişti. O andan itibaren, oyunun uyarlandiğı oyunun adı Gala, oyunun adı ise (Edibe Ayşsen Kutlugil'in eserinden hareketle) Hakiki Gala olarak değiştirildi. O halde metnin dilindeki bu edebi halin sorumlusu Edibe Ayşsen Kutlugil'di. Bu kendiliğinden çözülen sorun Edibe Ayşen Kutlugil'in kimliğine de açıklık kazandırmış oldu. Böyle bir metin yazdlğına göre Kerime Nadir ve Muazzez Tahsin Berkand'dan etkilenmiş olmaltyd. Bu kabul edilen etkileniş durumu, oyunun içinde bir melodramatik kurgunun oluşmasını da elverişli kılacaktı. ${ }^{27}$

25 Ayşe Bayramoğlu ve Ayşe Selen, "Bir Düşünceden Bir Sahne Metnine Yolculuk (Prova Günlükleri ve Notlar)", Hakiki Gala içinde (İstanbul: Mitos-Boyut Yayınları, 2010), 24.

26 a. e., 29.

27 a. e., $30-31$. 
$\mathrm{Bu}$ aşamadan sonra metnin yazılması konusunda Bayramoğlu'nun tamamen devreye girmesiyle metin son şeklini almıştır ve yukarıda da sözü edildiği gibi hem ağdalı cümlelerin hem de günümüz düşünce biçimini içeren tasvirlerin yer aldığı eklektik bir dil görmek mümkündür.

Metnin sahnelenmesi konusundaki yazar direktiflerinden bahsetmek gerekirse; dekor bir masa, iki sandalye ve bol ışıtan ibarettir ve kendilerinin temin ettiği ve süslediği izlenimini verir. Provalar sırasında dekorun da oyunun dili gibi "kitsch" olmasında karar kılınmıştır. ${ }^{28}$ Oyunun açılışında Müesser Hanım ve Lütfi Bey, sahneye girip ışıkları bir bir açtıkça seyircinin bakışına, seyredilme durumuna daha da açılır ve "kendilerini gösterme" telaşesine girerler. Seyirciye "Hoş geldiniz" dedikten sonra ikisi de birer kitap çıkarır; kitapların üzerinde "HAKİKİ GALA" yazmaktadır. Okumaya başlarlar, aslında ezberden okumayı niyet etmektedirler ama beceremezler; kitaba geri dönerler, bu kez gözleri görmez ve gözlükle okumaya çalışırlar... Kısacası acemi bir başlangıç yaptıklarını anlarlar ve "Baştan alalım" diyerek giriş kısmını tekrar ederler; öyle ki, ilkinde beceremezler ve bir kez daha hızlandırarak tekrar ederler... Öndeyiş kısmında da bir kez daha bocalamamak için kendi hayat hikâyelerinin nasıl buluştuğunu direkt olarak kitaptan okumaya başlarlar:
MÜESSER HANIM
Müesser Hanım...
$L \ddot{U T F I} B E Y$
...ve Lütfi Bey... o güne dek birbirlerinin mevcudiyetinden
habersiz bu hoyrat dünyada apayrl, yoklukları bile hissedilmeyecek denli stradan hayatlar sürmüş bu iki zat...
[...]
MÜESSER HANIM
...bir Hidrellez gecesi yine birbirlerinden habersiz, her vakit olduğu gibi gerçekleşememiş hayallerini düşünerek uykuya dalarlar. Kaderin cilvesi midir, bilinmez, apayrı uykuların derinliklerinde süzülen Müesser ve Lütfi'nin yolları tek ve ortak bir rüyada, hayatlarının galasında kesişir... LÜTFI BEY
...Bir kere olsun ramp ışılklarına, sahneye çılkabilme; bir kereliğine de olsa kendilerini gösterme şansını bulmuşlardır. Ama bu hayalin vücuda gelmesi o kadar kolay değildir, öyle şıpın işi olmayacaktır. Hayalini kurdukları ve kendilerini bekleyen sahnenin yolu karanlıktan geçer, zira bilinir ki her sahne açılmadan evvel zifiri karanlıktır. MÜESSER HANIM Kendi cılız ışılarıla kat ettikleri bu meşakkatli yolda, önlerine çıkan bu firsatın verdiği coşkuyla hiçbir şeyden yılmazlar. Nerede sahne alacaklarını, ışı ̆̆ı nasıl bulacaklarını tez vakitte öğrenirler. Lakin gösteri vakti geldiğinde de hiçbir şey tereyağından kıl çeker çeker gibi olmayacaktır [... $]^{29}$

Gerçekten de dedikleri gibi kolay ilerlememektedir. Bu kez de okumadan sonra kendi okuduğunu anlamama, diğerinin okuduğunu anlama üzerine bir tartışmaya girerler. Bu kısmı oynayacak oldukları gerçeğini hatırlayıp bir kez de okumadan "oynama”ya çalışırlar. Bu kez fena gitmezler ve metinde biraz daha ilerlerler. Oynadıkları metnin bizatihi kendisinin baştan almaları ve tökezlemeleri içerdiği görülür. Daha sonra sağ ve sol kulisten aynı anda girecekleri

28 a. e., 34 .

29 Ayşe Bayramoğlu, Hakiki Gala (İstanbul: Mitos-Boyut Yayınları, 2010), 54-55. 
direktifini de söyler; ardından dedikleri şekilde oynarlar. Bu sırada "Lütfi Bey narekesini çıkarır ve passo doble'nin introsunu çalar, ardından 'dem tutmaya' başlamasıyla birlikte Müesser Hanım iğreti bir Gala sunuşu yapar". ${ }^{30}$

Gala sunuşunun ardından önce Müesser Hanım, sonra Lütfi Bey uzun tiratlarıyla kendilerini tanıtırlar. Bu bölüm, oyunda üçüncü sayfa haberlerinden alınma hayat hikâyelerini anlattıkları ilk yerdir. Seyirciyi sıkacakları endişesini taşımaktadırlar ve bunu seyirciye ifade ederler; fakat kendileri hakkında verdikleri bilgiler oldukça uçuk ve trajiktir. Hikâyelerinin içerdiği trajedinin çekiciliğine rağmen çoğunlukla anlatım sırasında bu hadiselerin üzerinde durmazlar; aktarımın kendisiyle ilgilenirler ve öncelikleri seyircinin nabzını tutmaktır. Fakat bazı anlar öyle çarpıcıdır ki kendilerini bu anların “içine düşmek”"ten alamazlar. ${ }^{31}$ Oluşan yoğun havadan çeşitli stratejilerle birbirlerini çıkarmaya çalışırlar: Müesser Hanım polisli, tabancalı, evden kaçmalı, dayak yemeli hikâyesinin sonunda bozuk bir plak gibi, “...dayanılır gibi değil... Ölmek istiyorum, ölemiyorum... Dayanılır gibi değil...” demeye başlayınca Lütfi Bey bir hamle ile anlatım sırasını devralır. ${ }^{32}$ Benzer bir şekilde, Lütfi Bey'in cinsel istismarlı, bıçaklı, kanlı, dayaklı hikâyesinin kendisi için sarpa sardığı bir noktada Müesser Hanım elindeki kitabı yere düşürür ve böylece Lütfi Bey irkilerek içine girdiği tuhaf halden çıkar. ${ }^{33} \mathrm{Bu}$ şiddet dolu olayları mağdurlarının ağzından dinlemek ve takip etmek okuyucu-seyirci için dehşete düşürücü olduğu ölçüde çekicidir. ${ }^{34}$ Anlatıcıların içine düştüğü şekilde gibi okuyucu-seyirci de bu hikâyelere ve anlatıcılara kapılıverir. Dahası, tüm bunların başından geçtiğini iddia eden ama en nihayetinde kurmaca bir dünyadan bize seslenen bu anlatıcıların karizmasına tutulur ve onlara güvenir.

Oyunun devamında Lütfi Bey de hikâyesini tamamladıktan sonra araya yine şarkılı ve danslı bir kısım girer ve hikâyelerine kaldıkları yerden devam ederler. Bu bölümde de sahnedeki ikili, bir nevi “sırayı kapmaca oyunu” yla laflarını balla kesip sürekli kendi hikâyelerinin devamını anlatmaya çalışır; daha fazla görünür olma konusunda adeta bir yarış halindedirler. ${ }^{35}$ Burada da bambaşka ve zorlu hayatlardan gelen bu iki insanın bir Yeşilçam filmindeki gibi, bu hayata tutunamayan iki kişiyken nasıl birbirlerine tutundukları ve bir aşka başladıkları anlatılır. Sahne üzerindekilerin anlattıkları hikâyeler, seyircinin ikna olma sınırını zorlayacak kadar absürd bir kurguya sahiptir. Yine de, Tiyatrotem'in sahnelemesinde oyuncuların anlatıcı olarak seyirciyle kurdukları ilişkinin gerçeklik zemini, bu garip ikiliye sempati duymayı ve ikna olmayı sağlamaktadır. Zaten aksinin yaşanması, yani seyircinin ikna olmaması ve öyküye kapılamaması durumu, metnin ve kurgunun yazının devamında bahsedilecek olan sürprizli sonunun da boşa düşmesi anlamına geleceğinden

30 a. e., 56.

31 Ceren Özcan, Çağdaş Tiyatroda Anlatı: Tiyatrotem Üzerine Bir İnceleme (İstanbul: Mitos-Boyut Yayınları, 2018), 73-75.

32 Bayramoğlu, Hakiki Gala, 59.

33 a. e., 61.

34 Atay, Görünüyorum O Halde Varım: “Meşhuriyet Çă̆l”’nda Kültür ve İnsan, 44.

35 Bayramoğlu, Hakiki Gala, 63-78. 
ötürü oyuncuların seyirciyle kuracağı ilişkinin şimdi-ve-burada olma halini muhafaza etmesi ve anlatıcıların naif tavrı oyun için olmazsa olmazdır.

Oyunun bir sonraki bölümü Lütfi ve Müesser' in birbirlerini bulmalarının ardından birlikte yeni bir serüvene başlamalarıyla ilerler. İkili başlarını sokacak bir ev bulmuş ve her şeye sıfırdan başlamışlardır. Gündüzleri Lütfi işteyken Müesser komşuları yazar Edibe Hanım'la vakit geçirmeye başlamıştır. Bu bölümde seyirciye Edibe Hanım'ı anlatmaya başlarlar. Kirayı ödeyemeyip kaldıkları evden kovulunca Edibe Hanım onları evine alır. O aslında bir oyun yazmıştır fakat hiçbir yayınevi tarafından basılmamaktadır ve kadıncağız her kapıdan geri döndürülmektedir. Lütfi ve Müesser yazar evde yokken yazılarını okumaya başlarlar. Seyirciye, mahcup olduklarını ama kendilerini alamadıklarını söylerler. Onlara göre Edibe Hanım'ın oyununun basılamamasının sebebi, oyunun kapağında “yazılanların gerçek değil hayal ürünü olduğu”nun yazmasıdır. Dolayısıyla Edibe Hanım’a yardımcı olabilmek için, yazacağı yeni hikâyenin gerçek karakterleri olmayı; yani ona kendi hikâyelerini yazmasını teklif ederler. Edibe Hanım başta bunun "edebi hırsızlık" ve "ucuz şöhret” olduğunu düşünse de sonunda parasızlıktan haciz memurları kapısına dayandığında kabul eder. Ama bir şartı vardır: Kimliklerini gizleyecek, metinde Lütfi ve Müesser'e takma ad verecektir. Yazılan bu yeni romanı çok tutulur; öyle ki, gazeteciler roman kahramanlarıyla tanışmak için yazarın kapısında yatmaya başlarlar. Üçü de çok para kazanmasına, Lütfi-Müesser çifti ayrı bir eve çıkıp güzel bir yaşam kurmuş olmasına rağmen daha da fazlasını -daha fazla para ve daha fazla görünürlük, şöhret, beğeni- isterler. Sonunda Edibe Hanım’1 ekarte edip televizyona çıkmaya, hikâyelerini ifşa etmeye başlarlar. Medya da bununla yetinmeyip onlardan daha çoğunu istedikçe bu kez uydurmaya, abartmaya başlarlar. Hatta iş Edibe Hanım’ı karalamaya, onu kendilerini kullanmakla suçlamaya kadar gider. Fakat daha sonra Edibe Hanım'ın nasıl düşkün bir hale geldiğini gazetelerden öğrendiklerinde büyük vicdan azabı duyarlar ve onu hayata döndürürler. Yazara yaptıkları bu çirkinlikleri gazetelerde ve televizyonlarda anlatmak isterler ama Edibe Hanım doğru biçimin "tiyatro" olduğunu düşünür ve şu an bu ikilinin oynamakta olduğu "Hakiki Gala" oyununu yazar. Bu bilginin de verilmesinin ardından seyircinin dinlediği bu anlatıda artık sona gelinmiştir. Tüm bu sıralanan olayları anlattıktan sonra bu ikili, anlattıkları her şeyin yalan olduğunu söylerler. Aslında Edibe Hanım gibi kendilerinin de üçüncü sayfa haberlerine meraklı olduklarını ve bunları sıradan hayatlarını enteresan hale getirmek için evlerinde birbirlerine oynadıklarını; bu hikâyelere kendilerini kaptırdıklarını ve adeta yaşar hale geldiklerini itiraf ederler. Seyirciyle şimdiye kadar paylaştıkları bilgiler içinde sadece Edibe Hanım; ona üçüncü sayfa haberlerinden devşirdikleri özgeçmişlerini anlatmaları; ve onun da bu hikayelerin romanı olan "Gala" romanını yazması gerçektir. "Gala" romanının bu sahte kahramanları "Hakiki Gala" oyununun gerçek kahramanlarına dönüşmek için, meğer oyun boyunca hazırladıkları bu tiyatro oyunu ile gerçeğe ulaşmak için çabalamıştır. Oyunun sonunda da seyircinin nezdinde Edibe Hanım'dan bir kez daha af dileyerek, başladıkları gibi passo doble'leriyle sahne ışıklarını bir bir söndürüp karanlığa karışırlar. 
Müesser ve Lütfi'nin yaptığı itirafla ve oyunun katmanlı yapısını ifşa etmeleriyle oyun, seyir yerindekileri ters köşe yapmaktadır. Zira, bu bölümün başında da sözü edilen, günümüz insanının aşırı özgünlük ihtiyacı ve bunun çoğunlukla sahne ve metinlerde bulduğu boşluktan kendini gösteriyor oluşu Hakiki Gala ile bir üst boyutta tartışılmaya çalışılmış ve seyircinin günümüz tiyatrosundan görmeye alışık olduğu anlatı zeminini ve anlatıcı kimliklerini alaşağı etmiştir. Oyun göstermeci ve her şeyiyle açık bir üslup benimsemesine rağmen anlatılan hayat hikâyelerinin ve yaşadıkları vahşetin ürkütücü gerçekliği seyircinin ister istemez oyun süresince sahnede gördükleri anlatıcılara hayranlık duymasını beraberinde getirmiştir. Seyirciye üstten ya da alttan bakmamanın; denk ve sahici bir ilişki kurabilmelerinin de bu durumdaki payı yadsınamazdır. Ceren Özcan da Tiyatrotem üzerine hazırladığı kitabında bu incelikli yapıya şöyle yer vermiştir:

Tiyatrotem 'in Hakiki Gala oyunu temsili olanı (Müesser ve Lütfi'nin kurmaca kendilikleri), temsili olan (Gala) ile temsil aracıllğgyla (Tiyatrotem 'in gösterimi) anlatırken bunu izleyicisiyle hakiki bir iletişim kurarak yapmaktadır. Hakiki olan gösterim sırasında içinden geçilen anlardır; bazen anlatısal, bazen de dramatik olan anlar. Oyuncunun, rol kişisinin ve izleyicinin aynı anda başına bir şey gelmesini sağlayan bu anlar sahici olmak zorundadır ki oyun amacına ulaşabilsin. Müesser ve Lütfi oyun süresince izleyiciyi kandırmaktadır. Oyunun sonunda izleyiciye yalanların itiraf ederken oyun kişilerinin tutunduğu, tam da oyunun eleştirdiği, başka özgünlükleri devralarak gerçeğe ulaşma düşüncesidir. ${ }^{36}$

Özetle, oyunda kendisini temsil etmeden var olamayan öznenin medya tarafından teşhir edilen başka hayat hikâyelerine ve mahreme duyduğu hayranlığın ve tiyatronun temsiliyetinin bir arada düşünüldüğü görülmektedir. Tüm bu süreci oyun sonunda ifşa ederek seyirciyi de hakikat ve temsiliyet üzerine düşündürmesi özelinde Hakiki Gala, şöhret çağı 2000'lerin tiyatro yazını ve sahnelemesi anlamında teatral araçlarının araştırıldığı bir oyun olmasıyla özel ve özgün bir yerde durmaktadır.

Bayramoğlu'nun bir sonraki bölümde ele alınacak oyunu Beyaz Yalanlar da, Hakiki Gala'nın çıkış kaynaklarından biri olan reality show dünyasını sahneye taşımakta ve kanan-kandırılan konumunu, hazırladığı son ile yine ters yüz etmeye çalışmaktadır.

\section{Temsilin Temsili olarak "Reality Show" ve Gerçek Kurbanlar: Beyaz Yalanlar Oyunu}

Hakiki Gala'yı üreten Tiyatrotem ekibi gibi Bayramoğlu'nun kendisin de, yerel ve küresel ölçekteki konjonktürel değişimlerin o dönem hâlihazırda derdine düşmüş bir yazar olduğu söylenebilir. Beyaz Yalanlar metni de benzer bir sorgulamanın ürünü gibi gözükmektedir. Yazar, oyunun ilk taslağını 2009 yılında yazarlık eğitimini tamamlamak üzere hazırladığı tezi kapsamında kaleme almış ve tezini oyunu şekillendirme süreci üzerine kurmuştur. Hakiki

36 Özcan, Çağdaş Tiyatroda Anlatı: Tiyatrotem Üzerine Bir İnceleme, 71. 
Gala'da reality show dünyasının ve üçüncü sayfa haberlerinin hakikatini ve temsiliyetini sorgulama ve aynı zamanda anlatı kapsamında bu hikâyeleri "alıntılama" durumu varken, Beyaz Yalanlar oyununda reality show formatının sahne üzerine yerleştirilmesi ve programın kulis hazırlığının da tiyatro seyircisinin seyrine sunulduğu bir dramatik yapı karşımıza çıkmaktadır.

Son halini almadan önceki iki taslağına da erişme imkanı bulunan Beyaz Yalanlar oyununda, aynı apartmanda yaşayan ve komşu olan bir kadın ve bir adamın "Beyaz Yalanlar" adlı yarışma programına rakip yarışmacılar olarak katılmaları ve komşularını kurban olarak seçmeleri konu edilmektedir. İsimsiz şahıslar Adam ve 2. Kadın'ın 100.000 tl'lik ödülü kazanabilmek için komşuları ve dul kalmış olan 1. Kadın'a programın ismiyle müsemma "beyaz yalanlar" söyleyerek onu kandırmaya çalışır. Bu iki yarışmacının, kurbanları olan komşularını, hayatını değiştirmesi ve evinden çıkması konusunda ikna etmeye çalışmaları oyunun ana çatışmasını oluşturmaktadır. Yarışan komşular, her gün yeni stratejilerle ilerledikleri ve gerilimin tırmandığ yarışmada kazanan olabilmek için, daha önce bir kere bile selamlaşıp sohbet etmedikleri ve evlerine bile gitmedikleri 1. Kadın'1, bu kez yarışma gereği yaşadığı hayatın altından girip üstünden çıkarak kendi planlarına dâhil olması için kandırmaya uğraşmaktadır. ${ }^{37} \mathrm{Bu}$ üç rol kişisinin dışında tabii ki "Beyaz Yalanlar” programının sunucusu “dış ses” olarak yarışmacıları yönlendirmekte ve rekabeti artırıp gerilimi sürekli tırmandırmaya çalışmaktadır. Dış Ses’i oyun içindeki en büyük yadırgatma unsuru olarak gören yazar, oyunun yarışma katmanı ile yarışmacıların kurbanla olan sahnelerini ayrıştırmak için Dış Ses'in yarışmaya müdahale etmesinin ve gerektiğinde baskı unsuru oluşturabilmesinin kritik olduğunu belirtmiştir. ${ }^{38}$

Oyunun ilk taslağını da eklediği inceleme tezinde belirttiği gibi, ilk aşamada Bayramoğlu için 1. Kadın'ın kapalı dünyası çok daha merkezi bir durumdadır. Yazarın yola çıkış noktası kendini dış dünyaya kapamış ve kendi gerçeğini görmek istemeyen, aslında kendisine "beyaz yalanlar" söylemekte olan bu kadın karakter olmuştur. Fakat 1. Kadın'ın ölmüş kocası Salih'le olan ilişkisinde de barınan yalanları; yani aslında birbirlerini hiçbir zaman tanımamış oldukları ve belki de tanımak istemedikleri gerçeğini de önemseyen Bayramoğlu, bu genel sahtelik durumunu tüm oyuna taşımaya karar verir ve yarışma programı formatını kullanarak riya ve çıkar ilişkilerini irdelemeyi amaçlar. Bayramoğlu ayrıca reality show fikrinin "sahne üzerindeki olayların oluş zamanı ile bunların aktarım zamanının farkını da açıkça ortaya koyabileceğini", ve bunun reji için de elverişli bir durum olduğunu düşünmüştür. ${ }^{39}$ Bayramoğlu hem 1. Kadın'ın komşuları tarafından kendi çıkarlarınca kullanılmak istenmesini ve içinde bulunduğu duruma acımasını istemediği için, hem de "oyunu izleyenlerin kendi hayatlarına dönüp bakması ve benzer durumlara rastlaması halinde 'Ben de artık bundan vazgeçeyim' diyebilmesi” için

37 Ayșe Bayramoğlu, Beyaz Yalanlar (İstanbul: Mitos-Boyut Yayınları, 2012), 5-54.

38 Ayșe Bayramoğlu, “'Beyaz Yalanlar' Adlı Oyun ve Oyunun Yazım Süreci” (Yüksek Lisans Tezi. Kadir Has Üniversitesi, 2009), 14.

39 a. e., 12. 
oyunun komedi olmasını kendine şart tutmuştur. ${ }^{40}$ Yazar aynı zamanda oyunun bir yarışma programını içerdiği bilgisini, yani reality show katmanını seyirciye Hakiki Gala'daki gibi oyunun sonunda sunmak yerine oyunun açılışını Dış Ses ile yaparak seyir çerçevesini en baştan çizmeyi seçmiştir.

Zaten izleyici olarak tiyatroya bilinçli bir şekilde geliyor ve elimizdeki broşürden oyun ve karakterler hakkında ön bilgi alıyorken izleyiciden kendini bu oyuna kaptırmasını ve diş dünyayı unutmasını, gördüğ̈̈ her şeye inanmasını istemek bana saçma geliyordu"41

Yazar, tezinde yer verdiği yukarıdaki cümleleriyle de tiyatronun kurmaca olduğu bilgisinin hâlihazırda hedef aldığı seyirci kitlesinde bulunduğunu ve seyir algısıyla oynamak gibi bir niyeti olmadığını ifade etmiştir.

Tez sürecinde sunduğu taslak metne jüri tarafından yapılan geri dönüşler sonucunda revize ettiği ikinci versiyonunu da tezine ekleyen yazarın, son halini alan ve bu şekilde basılan Beyaz Yalanlar metninin evrimsel sürecini incelerken bu çalışması, yazın pratiğini görebilmek anlamında değerlidir. Oyunun geriliminin yükselmediği, 1. Kadın'ın oldukça saf gösterildiği, yarışmacıların kullandıkları yalanların ikna edici olmadığı gibi ${ }^{42}$ yorumlar alan Bayramoğlu, metnini buna uygun şekilde düzenlemiştir. Aynı zamanda, ilk taslağa yapılan geri dönüşlerden biri reality show programının tiyatroda sahnelenebilmesine yönelik olmuştur.

Benim bir reji önerisi olarak kabul ettiğim bir başka öneri ise izleyici konumlanmasında da netlik sağlayacak sinema perdesi önerisiydi. Bu perde sayesinde izleyici televizyon izleyicisiyle tiyatro izleyicisi arasında bir yerde kalacak ve tam da yapmak istediğim yadirgama halini yaşayacaktt. ${ }^{43}$

Set ortamı ile 1. Kadın'ın evini ayıran bir barkovizyon perdesi kullanılmasıyla sahnelemenin de çözüleceğini düşünen ve bu çözümü işlevli bulan Bayramoğlu, yazar olarak nihai metne bu şekilde bir sahneleme direktifi eklemeyi uygun bulmuştur. Bu direktifler sahne ile seyirciyi ayıran perdeye prime-time' da gösterilen türden birkaç reklamın yansıtılması ve "Beyaz Yalanlar” programının jeneriğinin akması gibi, kurbanın evi ile programın sunulduğu ve eve girme hazırlığının yapıldığı kulisi sahne üzerinde ayırmayı pekiştirecek önerilerdir. Bu anlamda, televizyonun yarattığg illüzyon ile tiyatronun kurmacalığını ifşa eden yapısı; yani tiyatroda seyir yerinin ancak hayali bir dördüncü duvarın ima edilmesiyle bertaraf edilebiliyor oluşunun bir olmadığının farkına varılmış olduğu söylenebilir. Dolayısıyla televizyonun yarattığı seyir illüzyonunu tiyatro sahnesinde böylesi bir katmanlı yapıyla yaratabilmek için bu barkovizyon çözümü kaçınılmaz görünmektedir.

Oyunun aşamalarına bakıldığında, oyunun başında Dış Ses programın sunuşunu yapmadan önce perdeye kurbanın evine yerleştirilen gizli kameraların çekmekte olduğu görüntü yansıtılır.

40 a. e., 11.

41 a. e., 13.

42 a. e., 64-65.

43 a. e., 66. 
Perde kalktığında seyircinin karşılaşacağı manzara, perdede izlemekte olduğu kaydın reel hali olacaktır. Dış Ses, programın formatını seyirciye tanıtırken bir yandan da perdeye ev içi görüntü, yani sahne üzerinde bulunan ve perde marifetiyle kamufle edilen mekan yansimaya devam eder. Jenerik müziğinin duyulmasıyla perdeye yarışmacıların, Adam ve 2. Kadın'ın görüntüsü yansır. Perde önüne gelip Dış Ses'in yönlendirmesiyle kendilerini tanıtırlar. Sonrasında sıra kurbanın tanıtımına geldiğindeyse şunları söylerler:

2. KADIN O da bu apartmanda oturuyor. Bizim yaşlarımızda. Dul. ADAM Kocası geçen yıl öldü. $O$ da kendini eve kapattı.

2. KADIN Tuhaf bir çiftti bunlar. Kadın evden çıkmaz, adam ara sıra çıkar, o da mecburiyetten herhalde. Pek gelen gidenleri de olmazdl. Evlerinde televizyon falan da yokmuş.

ADAM Bu devirde televizyon izlemeden olmaz ${ }^{44}$

Ardından yazı tura atılarak eve girecek ilk yarışmacı belirlenir ve perdenin kalkmasıyla yarışma başlar. ${ }^{45}$ Kurban kocasının ölüm yıldönümünü anmaktadır. 1. Kadın hazır olduğunda kapıyı çalar ve kurban tereddütle de olsa onu evine buyur eder. $\mathrm{Bu}$ giriş sahnesinden sonra oyun, rakiplerin sırasıyla eve girip kadınla bir komşuluk ilişkisi kurmaya çabalaması ve büyük ödül için kurbanı evden çıkmaya ikna etmeye çalışmasıyla devam eder. Bu süreçte seyirci aralarında geçen diyaloglardan bir yandan rakiplerin yalan mı gerçek mi olduğunu anlayamadığ 1 hayat hikâyelerini, bir yandan da kurbanın ölen kocasının nasıl özlemini çektiğini ve nasıl mutlu bir evlilikleri olduğunu takip eder. Rakipler sıra birbirlerine geçtikçe kuliste birbirlerini aşağılamayı ve kazanma hırsıyla çirkefleşmeyi sürdürür. ${ }^{46}$ Daha sonra programın ilk günü sonuçsuz bir şekilde kapanır. İkinci güne başladıklarındaysa yalan dozu da rekabet dozu da artmıştır. Yarışmacılar kurbanı ayartmak için kadınlık ve erkeklikleri üzerinden geliştirdikleri strateji üzerinde çalışmaya devam ederler. Adam, bir erkek olarak kurbanın dikkatini çekmek için soyunma hamlesi yapınca aralarında gelişen diyalog sırasında bir pot kırar:

1.KADIN Bir gelen olsa ... Şu halimize bak.

ADAM Kimse gelmez, merak etmeyin.

1. KADIN Nereden biliyorsunuz?

ADAM Ayarladik biz.

1. KADIN Nasil siz?

ADAM Kurallar gereği. ${ }^{47}$

Kulaklıktan Dış Ses'in uyarısını duyunca “komşu ziyareti kuralları”ndan bahsettiğini söyleyerek durumu toparlar. Fakat Adam bu kez rakibine saldırı üzerinden kurbanı yanına çekmeye çalışınca işler karışır. Dış Ses müdahale etse de yarışmacılar ödülü birbirine kaptırma

44 Bayramoğlu, Beyaz Yalanlar, 7.

45 a. e., 8.

46 a. e., $8-25$.

47 a. e., 30. 
niyetinde değildir ve sonunda her ikisi de kurbanın evine girer. Dış Ses bunun program tarihinde bir ilk olduğunu söyleyip reytinge oynar. ${ }^{48}$ Hatta yarışmanın gidişatı değiştiği için para ödülünü de yükseltmeye ve tansiyonu artırmaya başlar. ${ }^{49}$ Sonunda kurban dayanamaz ve içeri gidip elinde bir tabancayla döner. Yarışmacıları rehin alır ve sorguya çeker. Komşular suçu birbirlerine atınca da havaya ateş eder. Yarışmacılar kulise kaçar, kurban sakinleyince bu kez 500.000 TL'ye yükselmiş para ödülü için birlikte eve girmeyi kararlaştırırlar. Kurban silahla onları tehdit etmiş olmaktan pişman olduğunu söyleyip özür diler ama komşular blöf yapıp gitmeye davranır. Kurban her ikisinin teklifini de kabul ettiğini; Adam'la evlenmeyi, 2. Kadın'la da nereye isterse gitmeyi kabul ettiğini söyleyince de komşuları tarafından bir seçim yapmak durumunda bırakılır. Kurban kararsız kalıp seçim yapmadıkça yalnızlığa mahkûm olduğunu anlayınca da, hayatının görünmeyen gerçek yüzünü onlara bir bir anlatır. Kaynanasından neler çektiğini, kocası Salih'le küçük yaşta zorla evlendirildiğini, eşinin aslında gay olduğu ortaya çıkmasın diye mecburiyetten evlendirildiğini; kısacası madalyonun öbür yüzünü gösterir. Dış Ses hemen olaya müdahil olup seyirciye yarışmacıların bu "inanılmaz dram"la nasıl başa çıkacaklarını sorar. Yarışmacılar başta utanır ve kalakalır, sonra itirafları için sessizce anlaşırlar:
2. KADIN
Biz sana bir şey söyleyeceğiz.
$A D A M$
Birlikte
2. $K A D I N$
Evet. Biz ikimiz, birlikte. Sana yalan söyledik.
1. KADIN
Yine mi?
ADAM Yok, ilk geldiğimizde öyleydi. Şimdi değil.
2. KADIN Şimdi, gerçeği söyleyeceğiz.
DIŞSES Böyle yarışmacılar görülmedi sevgili seyirciler! Bugün bizi izlemeyenler gerçekten çok şey kaçırıyorlar! ${ }^{50}$

Yarışmada olduklarını açıklamaları beklenirken önce kendi hikayelerine yönelik söyledikleri yalanların itirafıyla başlarlar. Aslında tıpkı kurbanları gibi, ona sundukları yalan hayat hikâyelerinin zıttı olan, oldukça sıkıcı ve ne yazık ki gerçek olan hayatları vardır. Adam annesinin baskısı altında yaşamaktadır ve hiç evlenememiştir. Yarışmaya katılmaya komşusunun önerisiyle karar vermiştir. Bu durum aslında seyirci için de tanıdık bir durumdur. Zira, reality show yarışmalarının diğer televizyon programı türlerinden farkı, tam da "sıradan" olanın katılıp kendini gösterebildiği ve seyirlik hale geldiği bir tür olmasıdır. ${ }^{51}$ Diğer yarışmacı 2. Kadınsa, kocasından sevgi ve ilgi görmemektedir ve avuntuyu kendini televizyona vermekte bulmuştur. $\mathrm{Bu}$ iki kişi de yarışmaya başvururken, Atay’ın ifadesiyle “kimsenin kimseyi umursamadiğl, herkesin herkesten ürktügü bir 'kalabalık yalnızlıklar' dünyasında var olmanın ve var

\footnotetext{
48 a. e., 38.

49 a. e., 40.

50 a. e., 49.

51 Oya Şakı Aydın, "Şöhret Kültürü: Toplumsal Değişim ve Medyanın Rolü” (Doktora tezi, Marmara Üniversitesi, 2008), 237.
} 
'sayılma'nın yolunun artık çok daha fazla 'görünmek ve tanınmak'tan geçtiği sanısı"yla ${ }^{52}$ hareket etmişlerdir. Oyunun devamında kendi gerçekliklerini ifşa etmelerinin ardından, aynı zamanda bir yarışmada olduklarını ve 1. Kadın'ı nasıl kurban seçtiklerini itiraf ederler. 1. Kadın neden seçildiğini anlayamaz; yarışmacılar da onun tek başına var olabiliyor ve mutlu olabiliyor olmasını kıskanmalarını gerekçe gösterirler. Oyunun sonunda, ortada yarışma namına bir şey kalmadığını duyuran Dış Ses' in programı kapatması ve jenerik müziğinin ardından bir başlarına kalan oyun kişileri ne yapacağını bilemez ve gerçeği yaşamak konusunda bocaladıkları bir haldelerken oyun sonlanır.

Aslında Beyaz Yalanlar oyununun ilk taslağında, kurban 1. Kadın'ın tek başınayken, kendine söylediği yalanları itiraf ettiği uzun bir tiradı bulunmaktadır ve ardından "Salih, bana artık müsaade" diyerek kocasının anılarını ve evini bırakıp gider. 1. Kadın'ın bu eylemi neticesinde de yarışmacıların mücadeleleri boşa düşer. ${ }^{53}$ Fakat bu sonla, yarışmacıların söyledikleri yalanların foyasının ortaya çıkmaması sebebiyle ikinci taslakta bu son değiştirilir. 1. Kadın tabancayı alıp geldikten sonra yarışmacılar zorla ne olup bittiğini ve onu kandırdıklarını itiraf ederler ve ikinci taslak şu şekilde noktalanır:

\section{(1.Kadın silahını doğrultup sesin geldiği yöne doğru ateş eder. Dıı̧ Ses vurulur.) DISS SES Aaah! \\ (1.Kadın silahın görmeden 2.Kadın ve Adam "a doğrultur.) \\ 1.KADIN Rahat birakın beni! Huzurumu bozmayı! \\ (2.Kadın ve Adam kaçarlar.) \\ (Jenerik müziği bozuk bir şekilde çalmaya başlar. 1.Kadın yeniden evine girer. Duvardaki düğün fotoğrafinı alır, ışıkları söndürürken sinema / barkovizyon perdesi iner, yarışmanın jeneriği akar. $)^{54}$}

Oyunun komik olmasını en başından beri isteyen Bayramoğlu'nun hazırladığı bu ikinci son oldukça tuhaf ve bir o kadar da gülünçtür aslında; ama parodinin sınırlarında gezmemek adına yazarın yeni bir son tasarladığı düşünülmektedir. Metnin basım versiyonunda kurbanın asıl hikâyesini ve kendine bile itiraf edemediği yalanları anlattığı tiradın yarışmacılara yapılan bir itirafa dönüştürüldüğü ve oyunun sonunun yeniden değiştirilmiş olduğu görülmektedir. Zira Beyaz Yalanlar' da bu kez kandırılanın yalnızca potansiyel yarışmacı adayı konumundaki tiyatro seyircisi değil, oyundaki reality show yarışmacılarının bizzat kendileri olması niyet edilmiştir. Seyirci tarafından bir nevi ava giderken avlanma durumuna tanık olunmasının amaçlandığı oyun, yarışmacıların tıpkı medyada ya da yarışmalarda gördükleri insanlar hakkında olduğu gibi kurbanları hakkında da belli bir kabulleri ve yargıları olması; ama oyunun sonunda hiç de sandıkları gibi biri olmadığının ifşa edilmesi üzerine kuruludur. Bu bakımdan basım versiyondaki sonun daha fazla işlerlik sağladığı bir gerçektir. Kurbanın ve

52 Atay, Görünüyorum O Halde Varım: “Meşhuriyet Çağı”nda Kültür ve İnsan, 17.

53 Bayramoğlu, “'Beyaz Yalanlar' Adlı Oyun ve Oyunun Yazım Süreci”, 60.

54 a. e., $110-111$. 
yarışmacıların maskelerinin bir bir düştüğü ve yarışma formatının kendiliğinden hükümsüz kaldığı bir noktada çıplak gerçekleriyle kalan sıradan insanların acizliğini görmek seyirci için izlediği şeye dair geliştirdiği yargılar konusunda yeni bir deneyim geliştirmesi anlamında önemli gözükmektedir. Neticede, basım versiyonunda oyun şu şekilde kapanır:

ADAM Bize müsaade.

2. KADIN Kusura bakma, seni de yorduk bu iki gün.

1. KADIN Olsun canım. Komşuyuz biz.

ADAM İyi akşamlar.

2. KADIN İyi akşamlar.

1. KADIN Yine görüşür müşüz?

2. KADIN Bu sefer bende ama. Yok, olmaz. Oktay bu yarışma işini öğrenince beni evden kovabilir.

ADAM Bende de olmaz. Annem beni çoktan kovmuş olabilir.

1. KADIN Gitmeyin, kalın o zaman.

(Bir an...)

2. KADIN Yok canım. Yapmaz Oktay öyle şey. Göstermez ama sever beni. Niye kovsun? Değil mi?

1. KADIN Tabii.

ADAM Annem de sever beni. Özlemiştir hem. Sarılır şimdi kapıyı açınca. Değil $m i ?$

1. KADIN Tabii.

(Bir gidememe hali...) $)^{55}$

Oyunun bu son cümlelerinde, gerçeğin kendisiyle karşılaşmanın verdiği ağırlığı taşımanın oyun kişilerine zor geldiği ve ilk firsatta kendi beyaz yalanlarına tutunmaya çalıştıkları ve kaçtıkları görülmektedir. Bir çeşit geçiştirme haliyle ve yakında görüşme vaadiyle sahneden ayrılan bu kişileri gören seyircinin salondan ayrıldıktan sonra nasıl bir gerçekliğe dönecekleri meselesi, kendileriyle yüzleşme ya da kaçmayı seçme noktasında yine kendilerine bırakılmış durumdadir.

\section{Sonuç Yerine}

Neoliberalizm, bireyleri mevcut iş piyasası ve medya gibi mekanizmalar aracılığıyla birey olarak yeniden konumlamış durumdadır. Küreselleşmeyle birlikte birey kendisinin ölçülebilir değerini kendini teşhir etme yoluyla belirlemeye çalışır ve bir meta olarak kendisini piyasa dolaşımına sokar. Bu mekanizmanın işlerliğinde özel olanın kamuya teşhir edilmesi durumu oldukça kritiktir ve reality show dünyası bu algının pekiştirilmesinde halen önemli bir işleve sahip gibi gözükmektedir. ${ }^{56}$ Reality show programları ile yaratılmış olan yeni kitle kültüründe

55 Bayramoğlu, Beyaz Yalanlar, 53-54.

56 Özlem Y1ldız, "Selves on Display: Neoliberal Subjectivities in Turkey in the First Decade of the Twenty-first Century through the Lens of Reality TV Shows" (Yüksek Lisans tezi, Boğaziçi Üniversitesi, 2013), 41-42. 
artık "hayatın içinden kurgu çıkarmanın ötesinde, kurgunun hayata geçirilmesi söz konusu"dur. ${ }^{57}$ “' 'Gerçek' hayatın izdüşümlerini kurgunun içinde görmekten çok, üretilmiş kurgunun, yani 'hayal'in izdüşümleri' hayatın içine girmektedir. ${ }^{58}$

Gerçek ve kurgunun sınırlarının bulanıklaştığına dair bir tartışmaya girişildiğindeyse tiyatrodan söz etmemek tartışmayı eksik bırakacaktır. Tıpkı televizyonun geldiği nokta gibi, kültür endüstrisinin hâkim söylemini yeniden üretme tehlikesiyle her zaman karşı karşıya olan tiyatro sahnesinin, tam da bu nedenle çağın insanının pasif bir alımlayıcı olup seyretme hazzına ve illüzyonuna kapılmasının ötesinde düşünsel bir deneyim yaşayabilmesi için kendini sürekli revize etmesi ve beslemesi gerekli gözükmektedir. Fakat günümüz Türkiye'sinde ve ana akım tiyatroda yeterince varlık gösteremeyen ve sesini duyuramayan 2000 sonrası güncel oyun yazarlarımıza bakıldığında, Oğuz Arıcı'nın da vurguladığı gibi görünürlük bakımından "kendini ifade edemeyen insanların sesi olma" eğiliminde olmakla birlikte bu yazarların temel motivasyon kaynağının öncelikli olarak "kendini ifade etme arzusu" 59 olduğu söylenebilir. Bu da bağımsız tiyatro sahnelerinde hem yerel ve öznel hikâyelerin kendine yer bulmasını hem de sahnedeki oyun kişilerinin bir anlatıcı gibi konumlandığı performatif anlatılar oluşturulmasını beraberinde getirmektedir. ${ }^{60}$ Dramatik bir yapının içinde hikâye anlatan oyun kişilerine rastlandığ gibi, anlatısal kipin merkezde olduğu ve dramatik kipin ${ }^{61}$ alıntılandığı örneklere rastlamak da mümkündür. 2010'larla birlikte tiyatro yazarlığı serüvenine başlayan Ayşe Bayramoğlu’nun bu yazıda ele alınan oyunları da, yazarın tiyatroda hem anlatı meselesini araştırdığı hem de bu "kendini ifade etme arzusunun" sosyolojik boyutunu seyircinin izleme alışkanlıklarıyla oynayarak araştırmaya çalıştığı oyunları olarak kabul edilebilir. Hem tiyatroda hem televizyonda kolayca melodrama dönüşebilecek hikâyelerin sahneye taşınmasında Bayramoğlu, yazıda söz edilen iki oyununda trajikomik ve ironik olanın ortaya konduğu bir yapı oluşturmaya çalışmıştır. Takip ettiği bu stratejiye bakmak da, görünür olma çabasının merkeze yerleştiği 2000'lerin tiyatroda kendine nasıl yer edindiği ve edinebildiği meselesini anlayabilmek açısından önemli olabilir.

Tiyatroda Brechtyen bir anlayışla konvansiyonel seyir alışkanlıklarını kırmaya yönelik atılan adımlar olarak değerlendirilebilecek Hakiki Gala ve Beyaz Yalanlar oyunları, katmanlı yapıları ve örtüşen temalarına rağmen sahnelemedeki farklı teatral hamleleriyle bir arada değerlendirilecek iki oyun olarak seçilmiştir. Ayşe Bayramoğlu'nun Tiyatrotem ile işbirliği sonucu yazmaya nail olduğu sahneleme metni Hakiki Gala'da özgünlük ve temsiliyet meselesinin seyirciyle kurulan ilişkiyi de hesaba katarak teatral bir zeminde araştırıldığı, Beyaz Yalanlar

57 Atay, Görünüyorum O Halde Varım: “Meşhuriyet Çağı”"nda Kültür ve Insan, 71.

58 a. e., 71.

59 Oğuz Arıcı, “Türkiye'de Oyun Yazarlığında Yeni Eğilimler 1”, Tiyatro Eleştirmenliği ve Dramaturji Bölümü Dergisi, 25 (2017), 17.

60 Gümüş, "2000 Sonrası Çağdaş Türk Tiyatrosunda Yeni Bir Estetik: Performatif Anlatı”, 241.

61 Anlatısal kip ve dramatik kip ayrımının ortaya konduğu bir tartışma olarak bkz: Özcan, Çağdaş Tiyatroda Anlatı: Tiyatrotem Üzerine Bir Inceleme, 26-33. 
oyununda da reality show formatıyla tiyatrodaki dramatik yapının bir aradalığının estetik ve tematik ayrımının peşine düşülmeye çalışıldığı görülmektedir. Tiyatrotem ile yollarının kesişmesi ve ekibin teşvikiyle, "tay tay" adımlar atan bir yazar adayı iken Hakiki Gala oyunu ile ödüllü bir yazara dönüşen Bayramoğlu'nun kaleme aldığı metinler gibi tiyatromuzun yerleşen seyir alışkanlıklarıyla oynamaya çalışan metinlerin üretilebilmesi için, belki de tam da bu nedenle her daim kolektif bir yaklaşımı benimsemek önemli olabilir.

Peer-review: Externally peer-reviewed.

Conflict of Interest: The author has no conflict of interest to declare.

Grant Support: The author declared that this study has received no financial support.

Hakem Değerlendirmesi: Dış bağımsız.

Çıkar Çatışması: Yazar çıkar çatışması bildirmemiştir.

Finansal Destek: Yazar bu çalışma için finansal destek almadığını beyan etmiştir.

\section{KAYNAKÇA / BIBLIOGRAPHY}

Arıc1, Oğuz. "Türkiye'de Oyun Yazarlı̆̆ında Yeni Eğilimler 1”, Tiyatro Eleştirmenliği ve Dramaturji Bölümü Dergisi, 25 (2017), 1-34.

Atay, Tayfun. Görünüyorum O Halde Varım: “Meşhuriyet Çağı”"nda Kültür ve İnsan. İstanbul: Can Yayınları, 2018.

Bayramoğlu, Ayșe. “"Beyaz Yalanlar’ Adlı Oyun ve Oyunun Yazım Süreci.” Yüksek Lisans tezi, Kadir Has Üniversitesi, 2009.

Bayramoğlu, Ayşe. Hakiki Gala, İstanbul: Mitos-Boyut Yayınları, 2010.

Bayramoğlu, Ayşe ve Selen, Ayşe. "Bir Düşünceden Bir Sahne Metnine Yolculuk (Prova Günlükleri ve Notlar)", Hakiki Gala, 11-46. İstanbul: Mitos-Boyut Yayınları, 2010.

Bayramoğlu, Ayşe. Beyaz Yalanlar, İstanbul: Mitos-Boyut Yayınları, 2012.

Bayramoğlu, Ayşe. “Oyun Yazarının Bir Sahne Metni Oluşturmak Üzerine Deneyimleri”, Hakiki Gala, 4748. İstanbul: Mitos-Boyut Yayınları, 2010.

“Bu 'Pencere' Sizi Utandırmak İçin Açıldı”, Cumhuriyet, 30.12.2012, erişim 23.09.2020). https://www. cumhuriyet.com.tr/haber/bu-pencere-sizi-utandirmak-icin-acildi-394206

Çuhadar, Bahar. "Yerli oyun yazarlarının 5N1K's1." Radikal Hayat, 27 Mart, 2012. http://www.radikal.com. $\mathrm{tr} /$ radikal.aspx?atype $=$ haberyazdir\&articleid $=1083014$

Debord, Guy. Gösteri Toplumu, çev. Ayşen Ekmekçi- Okşan Taşkent. İstanbul: Ayrıntı Yayınları, 2018.

Gümüş, Yunus Emre. "2000 Sonrası Çağdaş Türk Tiyatrosunda Yeni Bir Estetik: Performatif Anlatı", Uluslararası Disiplinlerarası ve Kültürlerarası Sanat Dergisi, 6 (2018), 237-248.

Gürbilek, Nurdan. Vitrinde Yaşamak: 1980'lerin Kültürel İklimi, İstanbul: Metis Yayınları, 2001.

Özcan, Ceren. Çağdaş Tiyatroda Anlatı: Tiyatrotem Üzerine Bir İnceleme, İstanbul: Mitos-Boyut Yayınları, 2018. 
Sarıkartal, Çetin. "Klasik Dramatik Metinleri Bugün Buradan Anlatmak", Tiyatro Araşstırmaları Dergisi, 29 (2010), 67-79.

Sarıkartal, Çetin. "Varsayılan Kullanıcıyı Kenara Bırakmak: Neoliberalizm, Sinirbilim ve Oyuncu Eğitimi”, Dikmen Gürün'e Yazılar. Hazırlayan Yavuz Pekman ve Oğuz Arıc1, 514-525. İstanbul: Doğan Kitap, 2020.

Şakı Aydın, Oya. "Şöhret Kültürü: Toplumsal Değişim ve Medyanın Rolü”, Doktora tezi, Marmara Üniversitesi, 2008.

Şakrak, Bilgehan Ece. “Gerçekliğin Kurgulanmasında Reality-Show'lar”, Doktora tezi, Marmara Üniversitesi, 2014.

Tiyatrotem, Ayşe Bayramoğlu'nun Hakiki Gala adlı kitabına önsöz, 5-8. İstanbul: Mitos-Boyut Yayınları, 2010.

Yıldız, Özlem. "Selves on Display: Neoliberal Subjectivities in Turkey in the First Decade of the Twenty-first Century through the Lens of Reality TV Shows", Yüksek Lisans tezi, Boğaziçi Üniversitesi, 2013. 
